\title{
Kontribusi Tenaga Kerja Wanita Dalam Berusahatani di Desa Pegantenan Kecamatan Pegantenan Kabupaten Pamekasan
}

\author{
${ }^{1}$ Mohammad Shoimus Sholeh, ${ }^{2}$ Lia Kristiana, dan ${ }^{3}$ Maulidatul Hasanah \\ ${ }^{1}$ Program Studi Agribisnis Fakultas Pertanian Universitas Islam Madura \\ ${ }^{2}$ Program Studi Agroteknologi Fakultas Pertanian Universitas Islam Madura \\ ${ }^{3}$ Alumni Program Studi Agribisnis Fakultas Pertanian Universitas Islam Madura \\ e-mail: moh.shoimus@gmail.com
}

\begin{abstract}
Farming is an activity that is generally done by a man. Women as auxiliary workers who support the cultivation process. Women who work as farmers are indeed common and are mostly in rural areas. However, the contribution of women workers must be calculated in terms of time and income considering that in the process of cultivation many women workers are needed. The existence of female workers in Pegantenan Village makes it easy for farmers to carry out farming cultivation processes from pre-planting to post-harvest. Indirectly will contribute to family income. The purpose of this study was to analyze the decision-making factors in becoming a female labour and analyze the role and contribution of women farmers on household income. The analytical method used was multiple linear regression analysis. The results showed that family income factors, the number of family dependents and the distance from the house to the rice fields influenced the decision of women to work in the process of crop cultivation. While the contribution of farm woman's income was $27.98 \%$ of the total household income.
\end{abstract}

Keywords: labor, female agriculture labour, farming

\begin{abstract}
Abstrak. Bertani merupakan kegiatan yang umumnya dikerjakan oleh seorang laki-laki. Wanita sebagai tenaga kerja pembantu yang menunjang dalam proses budidaya. Wanita yang bekerja sebagai petani memang sudah umum dan rata-rata berada di daerah pedesaan. Akan tetapi kontribusi pekerja wanita harus diperhitungkan dari segi waktu dan pendapatan mengingat dalam proses budidaya banyak membutuhkan tenaga kerja dari wanita. Keberadaan pekerja wanita di Desa Pegantenan mempermudah para petani dalam melakukan proses budidaya usahatani mulai pra tanam sampai pasca panen. Secara tidak langsung akan memberikan kontribusi pendapatan terhadap keluarga. Tujuan penelitian ini yaitu menganalisis faktor pengambilan keputusan dalam menjadi tenaga kerja wanita dan menganalisis peran dan kontribusi wanita tani terhadap pendapatan rumah tangga. Metode analisis yang digunakan yaitu menggunakan analisis regresi linierberganda. Hasil penelitian menunjukkan bahwa faktor pendapatan keluarga, jumlah tanggungan keluarga dan jarak dari rumah ke sawah mempengaruhi keputusan wanita untuk bekerja dalam proses budidaya tanaman. Sedangkan kontribusi pendapatan wanita tani sebesar 27,98\% dari total pendapatan rumah tangga.
\end{abstract}

Kata kunci: tenaga kerja, wanita tani, usahatani.

\section{PENDAHULUAN}

Perkembangan pembangunan semakin hari semakin meningkat dengan cepat dan memberikan kesempatan bagi wanita yang ingin berperan disektor publik atau dunia kerja. Sejak terbentuknya kebijakan pemerintah yang dikenal dengan kebijakan peran ganda perempuan, saat ini perempuan Indonesia sudah mulai terlihat dengan jelas diberbagai bidang pekerjaan (Azizah, 2017).

Salah satu pekerjaan yang membutuhkan tenaga kerja wanita yaitu dibidang pertanian. Bertani merupakan kegiatan yang umumnya dikerjakan oleh seorang laki-laki. Wanita sebagai tenaga kerja pembantu sebagai penunjang dalam proses budidaya. Akan tetapi terdapat tanaman yang dibudidaya dalam proses pra tanam sampai pasca panen didominasi oleh tenaga kerja wanita. Hal ini menunjukkan bahwa wanita tani memiliki sumbangsih dalam keberlanjutan usahatani serta sumbang pendapatan yang diterima sebagai tenaga kerja wanita tani. Arsal et al. (2017) mengemukakan bahwa petani perempuan memiliki peran multi dimensi dalam meningkatkan ekonomi rumah tangga. Enete et al. (2010) mengatakan bahwa perempuan sebagai peran utama dalam sektor pertanian khususnya di negara berkembang.

Tenaga Kerja wanita pedesaan dikenal memiliki peranan penting sebagai salah satu tonggak penghasil pangan. Mereka terlibat dalam semua tahap kegiatan, mulai dari persiapan pengolahan lahan, sampai dengan pemasaran hasil, khususnya pada kegiatan penyiangan, panen, pasca panen, dan pemasarannya (Ervinawati et al., 2015). Endang et al., (2014) mengatakan bahwa peningkatan produksi usaha tani perlu dibarengi dengan adanya peningkatan efisiensi tenaga kerja keluarga tani. Salah satu alternatifnya yaitu dengan melibatkan wanita dalam proses budidaya usahatani karena mempunyai karakter telaten, sabar serta kontrol dalam pengambilan keputuan.

Kecamatan Pegantenan merupakan salah satu kecamatan yang terletak di Kabupaten Pamekasan yang mana banyak wanita yang bekerja sebagai petani disamping sebagai ibu rumah tangga khususnya di Desa Pegantenan. Suami dari wanita tani tersebut umumya bermata pencaharian sebagai petani dan juga non pertanian seperti tukang bangunan, pedagang, supir, tukang becak dan pegawai swasta. Wanita yang bekerja sebagai petani memang sudah 
umum dan rata-rata berada di daerah pedesaan. Akan tetapi kontribusi pekerja wanita harus diperhitungkan dari segi waktu dan pendapatan mengingat dalam proses budidaya banyak membutuhkan tenaga kerja dari wanita.

Wanita tani Didesa Pegantenan selain berperan sebagai ibu rumah tangga dan membantu suami, mereka membantu pula dalam pendapatan ekonomi rumah tangga sepertimenjadi tenaga kerja wanita tani (buruh tani). Bentuk bentuk partisipasi dalam berbagai kegiatan yang dilakukan oleh para wanita tani seperti penyiapan lahan, penanaman, panen, pasca panen, dan pemasaran, dan juga memiliki peran ganda lainnya.

Peran lain yang dilakukan oleh para wanita tani berupa kegiatan kegiatan sosial kemasyarakatan. Kegiatan sosial yang sering dilakukan di lingkungan masyarakat tidak luput dari peran wanita ibu rumah tangga diantaranya acara selamatan, pernikahan, akikah, dan acara sosial lainnya. Mereka memiliki kontribusi dan partisipasi penting dalam mendukung pelaksanaan dan keberhasilan setiap kegiatan atau acara yang dilakukan di lingkungan masyarakat.

Pengambilan keputusan wanita untuk bekerja berkaitan untuk memenuhi kebutuhan sehari-hari atau sebagai tambahan penghasilan dari pendapatan rumah tangga. Hal ini selaras dengan penelitian Hasil penelitian Bano et al. (2012), Ware (2014) dan Arsal el at. (2017) menunjukkan wanita yang bekerja memiliki peran dan kontribusi dalam memenuhi kebutuhan rumah tangga. Penelitian Ilma et al. (2015) menunjukkan bahwa kontribusi tenaga kerjawanita tani terhadap pendapatan usahatani lebih dari 50\% dari total pendapatan rumah tangga.

Talipi et al. (2018) mengungkapkan bahwa wanita memiliki kontribusi terhadap peningkatan pendapatan rumah tangga. Pendapatan bukan satu-satunya faktor yang mempengaruhi dalam pengambilan keputusan. Karakteristik rumah tangga juga akan berdampak pada perilaku wanita dalam membuat keputusan untuk bekerja sebagai buruh tani seperti jumlah tanggungan keluarga, pengeluaran untuk kebutuhan sehari-hari dan pendidikan karena disamping menjadi tenaga kerja diharapkan juga mampu mengelola kebutuhan sehari-hari.

Keberadaan pekerja wanita di Desa Pegantenan mempermudah para petani dalam melakukan proses budidaya usahatani mulai dari persiapan lahan sampai dengan pasca panen. Secara tidak langsung akan memberikan kontribusi pendapatan terhadap ekonomi rumah tangga. Pendapatan atau upah yang diterima oleh tenaga kerja wanita tani digunakan untuk memenuhi kebutuhan sehari-hari dan dapat menambah pendapatan rumah tangga. Maka penulis tertarik melakukan penelitian yang berjudul Kontribusi Tenaga Kerja Wanita Dalam Berusahatani Di Desa Pegantenan Kecamatan Kabupaten Pamekasan

\section{METODOLOGI PENELITIAN}

Kegiatan Penelitian dilakukan di Desa Pegantenan Kecamatan Pegantenan Kabupaten Pamekasan dengan pertimbangan daerah tersebut mayoritas banyak wanita yang bekerja sebagai tenaga kerja buruh tani dalam berusahatani khususnya untuk tanaman semusim yaitu tanaman bawang daun.

Populasi dalam penelitian ini adalah seluruh wanita tani yang terlibat dalam kegiatan usahatani bawang daun di Desa pegantenan Kecamatan pegantenan Kabupaten Pamekasan. Jumlah populasi dalam penelitian ini menurut hasil survey awal adalah sejumlah 60 wanita tani yang bekerja sebagai buruh tani. Populasi dalam penelitian ini adalah anggota wanita tani yaitu populasi wanita tani di Desa Pegantenan sebesar 60 orang akan tetapi tidak semua dijadikan sebagai responden.

Metode sampel yang digunakan dalam penelitian ini yaitu metode simple random sampling, yaitu proses pemilihan sampel dimana seluruh wanita tani mempunyai kesempatan yang sama untuk dijadikan responden dalam penelitian. Untuk menentukan jumlah sampel yang akan diwawancarai yaitu menggunakan rumus slovin yaitu sebagai berikut:

$$
\mathrm{n} \quad \begin{aligned}
=\frac{N}{N \mathrm{~d}^{2}+1} \\
=\frac{60}{60.0,1^{2}+1} \\
=\frac{60}{0,6+1} \\
=\frac{60}{1,6} \\
=37
\end{aligned}
$$

Dari hasil perhitungan diperolah sampel yang digunakan sebanyak 37 tenaga kerja wanita (buruh tani).

Jenis dan sumber data dalam penelitian ini meliputi (1) data primer yaitu data yang diperoleh langsung dilapangan melalui quesioner observasi dan wawancara langsung kepada wanita tani yang berkontribusi dalam kegiatan usahatani khususnya tanaman bawang daun di Desa Pegantenan Kabupaten Pamekasan. Adapun yang ditanyakan saat wawancara yaitu meliputi karakteristik petani, alokasi waktu serta pendapatan dalam sebulan dan (2) data sekunder Yaitu data yang diperoleh dari berbagai instansi terkait dengan penelitian ini seperti dari Kantor 
Desan, Dinas Pertanian, Badan Pusat Statistik (BPS) dan dari berbagai media yang berhubungan dengan kegiatan usahatani.

\section{Analisis Faktor-Faktor yang Mempengaruhi Pengambilan Keputusan Wanita dalam bertani}

Analisis yang digunakan adalah analisis regresi logistik untuk mengetahui faktor-faktor yang mempengaruhi keputusan wanita untuk bertani. Dalam model ini terdapat 6 variabel independen yang dimasukkan dalam model. Adapun model logit yang digunakan pada penelitian ini sebagai berikut.

$$
\operatorname{Ln} Y=\beta 0+\beta 1 X 1+\beta 2 X 2+\beta 3 X 3+\beta 4 X 4+\beta 5 X 5+\beta 6 X 6+e \ldots \ldots \ldots \ldots \ldots \ldots
$$

Dimana:

LnY : keputusan wanita untuk bertani dinyatakan dengan variabel dummy diberi nilai 1 dan jika wanita tersebut tidak bekerja diberi nilai 0 ,

$\mathrm{X} 1$ : Pendapatan rumah tangga (Rp),

$\mathrm{X}$ 2: Tanggungan keluarga (orang),

X3: Pendidikan (tahun),

X4: Waktu Luang (likert),

X5: Jarak rumah ke ladang (likert),

X6: Gotong-royong (likert),

$\beta 0$ : intersep,

$\beta 1$ - $\beta 6$ : koefisien regresi dan

e: variabel pengganggu

\section{Curahan Waktu Tenaga Kerja}

Untuk menghitung Curahan waktu kerja wanita tani dalam kegiatan usaha tani bawang daun dianalisis dengan menggunakan analisis HKP, Hernanto (1991) menyatakan bahwa tenaga kerja diukur menurut besarnya curahan kerja dalam suatu usaha tani sebagai berikut:

a) Jumlah jam dan hari kerja total. Ukuran ini menghitung seluruh pencurahan kerja sejak persiapan sampai panen yang menggunakan inventarisasi jam kerja ( 1 hari $=5$ jam kerja) lalu dijadikan hari kerja total.

b) Jumlah setara pria (man equivalent) yaitu jumlah kerja yang dicurahkan untuk seluruh proses produksi, diukur dengan hari kerja pria. Ini berarti harus menggunakan ketentuan berdasarkan upah yaitu untuk pria dinilai $1 \mathrm{HKP}$, wanita 0,8 HKP dan anak-anak 0,5 HKP.

Penelitian ini menghitung curahan waktu kerja wanita, maka dapat dihitung dengan rumus : HKP = 0,8 HKP $\mathrm{x}$ jam kerja/hari.

\section{Analisis Kontribusi Wanita Tani}

Pendapatan tenaga kerja wanita pada usaha usahatani memberikanterhadap pendapatan keluarga. Maka untuk mengetahuinya digunakan analisaperbandingan antara besarnya pendapatan tenaga kerja wanita (rupiah/bulan) dengan total pendapatan rumah tangga (Rupiah/bulan). Persamaanmatematikanya yaitu:

$\mathrm{KTKW}=\frac{\mathrm{PTKW}}{\mathrm{TPK}} \mathrm{X} 100 \%$

Dimana:

KTKW : Kontribusi tenaga kerja wanita tani (buruh tani) (\%),

PTKW : Pendapatan tenaga kerja wanita (Rupiah/bulan) dan

TPK : Total pendapatan keluarga (Rupiah/bulan).

\section{Karakteristik Petani}

\section{1) Umur}

Umur merupakan salah satu faktor yang mempengaruhi petani dalam menjalankan usahanya. Umur petani mempunyai pengaruh terhadap kemampuan dalam berfikir serta kekuatan fisik dalam bekerja (Mardani, 2017). Menurut Subri (2003) dan Badan Pusat Statistik (2018) kategori usia produktif yaitu mulai umur 15-64 tahun. Pada umumnya manusia yang tergolong ke dalam usia produktif akan memiliki tenaga yang lebih besar untuk bekerja dibandingkan dengan pada usia tidak produktif dan belum produktif.

Dari hasil penelitian (Tabel 1.) dapat dilihat bahwa umur tenaga kerja wanita $100 \%$ berada dalam usia produktif karena tidak ada yang dibawah umur 15 tahun dan di atas umur 64 tahun. Hal ini menunjukkan bahawa 
pada usia tersebut, tenaga kerja wanita tani akan memberikan hasil yang maksimal jika dibandingkan pada umut dibawah dan diatas usia produktif.

Tabel 1. Distribusi Responden Berdasarkan Golongan Umur di Desa Pegantenan Kecamatan Pegantenan Kabupaten Pamekasan

\begin{tabular}{cccc}
\hline No & Umur & Jumlah orang & Persentase \\
\hline 1. & $21-26$ & 6 & 16,2 \\
2. & $27-32$ & 8 & 21,6 \\
3. & $33-38$ & 6 & 16,2 \\
4. & $39-44$ & 6 & 16,2 \\
5. & $45-50$ & 8 & 21,6 \\
6. & $51-56$ & 3 & 8,2 \\
\hline Jumlah & & 37 & $100 \%$ \\
\hline
\end{tabular}

Sumber: Data Primer Diolah, 2019

Pada Tabel 1. Dapat dilihat bahwa paling sedikit wanita yang bekerja berada diumur 51-56 tahun dengan persentase sebesar 8,2\%. Ridwan et al., (2019) mengungkapkan bahwa secara fisik wanita tani yang berada dalam usia yang tergolong produktif memiki kemampuan baik secara pemikiran dalam mengambilkeputusan maupun fisik untuk dapat bekerja agar bisa membantu ekonomi keluarga. Anggraini et al., (2020) juga mengatakan bahwa wanita buruh tani yang berada dalam usia produktif memliki kemampuan berfikir dan lebih cepat dalam menyelesaikan kegiatan usahataninya, sedangkan buruh tani yang sudah berumur tua atau tergolong tidak produktif mempunyai pengalaman kerja usaha tani yang lama akan tetapi tidak dengan kemampuannya dalam menyelesikan kegiatan usahatani dan menyebabkan produktivitasnya akan menjadi berkurang dan produktivitas tersebut mempengaruhi terhadap pendapatan yang diterima.

2) Pendidikan

Pendidikan merupakan salah satu faktor penentu keberhasilan dalam melaksanakan kegiatan usahataninya. Tingkat pendidikan mempunyai pengaruh terhadap tingkat kemampuan petani dalam bertindak serta mengambil keputusan seperti dalam menerima adopsi inovasi. Petani di Desa Pegantenan Kecamatan Pegantenan memiliki latar belakang yang berbeda-beda mulai dari SD, Sekolah Menengah Pertama (SMP) dan Sekolah Menengah Atas (SMA). Mengenai pendidikan formal yang pernah diikuti wanita tani dari 37 responden di Desa Pegantenan dilihat pada Tabel 2.

Tabel 2. Distribusi Responden Berdasarkan Tingkat Pendidikan Formal di Desa Pegantenan Kecamatan Pegantenan Kabupaten Pamekasan

\begin{tabular}{cccc}
\hline No & Pendidikan & Jumlah orang & Persentase \\
\hline 1. & SD & 21 & 56,76 \\
2. & SMP & 8 & 21,62 \\
3. & SMA & 8 & 21,62 \\
\hline Jumlah & & 37 & $100 \%$ \\
\hline
\end{tabular}

Sumber: Data Primer Diolah, 2019

Pendidikan yang di maksud dalam penelitian ini adalah pendidikan formal yang diikuti oleh wanita tani responden. Pada Tabel 2. menunjukkan bahwa rata-rata tenaga kerja wanita yang berpendidikan SD di Desa Pegantenan Kecamatan Pegantenan sebesar 56,76\%. Hal ini menunjukkan bahwa rata-rata pendidikan masih tergolong rendah dan tidak menjadi hambatan untuk bekerja sebagai tenaga kerja wanita tani atau buruh tani karena tidak membutuhkan tingkat pendidikan yang tinggi akan tetapi lebih terhadap pengalaman bertani yang dimiliki.

Sejalan dengan hasil penelitian yang dilakukan oleh Prasetya et al., (2019) dan Rivai et al., (2020) diperoleh bahwa rata-rata pendidikan petani di pedesaan berpendidikan SD. Hasil penelitian Sari et al., (2019) menyebutkan bahwa sebanyak $91 \%$ petani masih berpendidikan SD. Dari beberapa penelitian menunjukkan bahwa rata-rata pendidikan petani maupun buruh tani masih tergolong rendah yaitu SD. Pratiwi et al., (2018) mengatakan bahwa petani di desa sebesar $44,25 \%$ berpendidikan SD.

\section{Pengambilan Keputusan Wanita Tani}

1) Pendapatan Rumah Tangga

Dari hasil uji (Tabel 3) diperoleh bahwa variabel pendapatan rumah tangga $\left(\mathrm{X}_{1}\right)$ nilai koefisiennya negatif dan nilai signifikansinya sebesar 0,005 sehingga dapat disimpulkan bahwa pendapatan rumah tangga berpengaruh 
nyata secara statistik dengan tingkat kesalahan 10\%. Tanda negatif menunjukkan bahwa semakin kecil tingkat pendapatan rumah tangga maka keputusan wanita tani untuk bekerja semakin besar.

Sejalan dengan penelitian Nilakusmawati et al. (2012) bahwa pendapatan keluarga berpengaruh nyata terhadap pengambilan keputusan wanita untuk bekerja. Rata-rata pendapatan rumah tangga di tempat penelitian yang istrinya menjadi tenaga kerja wanita yaitu Rp. 1.047.245,-/bulan, sedangkan tambahan dari hasil wanita bekerja ratarata Rp. Rp. 518.606,-/bulan. Tujuan istri bekerja sebagai tenaga kerja tani salahsatunya untuk membantu suami yang hasilnya digunakan untuk memenuhi kebutuhan sehari-hari. Jika suami mempunyai penghasilan yang besar maka istri lebih memilih untuk dirumah menjaga anak-anaknya. Kristina et al. (2019) menjelaskan bahwa keputusan wanita tani dalam bekerja dipengaruhi oleh pendapatan suami yang kurang, sehingga bisa membantu ekonomi keluarga.

\section{2) Tanggungan Keluarga}

Tanggungan keluarga $\left(\mathrm{X}_{2}\right)$ nilai signifikansinya sebesar 0,003, sehingga dapat disimpulkan bahwa jumlah tanggungan keluarga berpengaruh nyata secara statistik dengan tingkat kesalahan $10 \%$. Artinya semakin banyak jumlah tanggungan keluarga maka maka keputusan istri untuk menjadi tenaga kerja tani semakin besar. Rata-rata di tempat penelitian memiliki tanggungan keluarga sebanyak 5 orang. Banyaknya anggota keluarga akan meningkatkan jumlah pengeluaran tiap bulannya, makadari itu wanita berkeputusan untuk menjadi tenaga kerja tani.

Anggraini et al., (2020) mengatakan bahwa jumlah tanggungan keluarga akan berpengaruh terhadap motivasi wanita buruh tani untuk bekerja. Semakin banyak jumlah tanggungan keluarga maka biaya pengeluaran sehari-hari juga semakin bertambah, sehingga memotivasi wanita untuk bekerja menjadi buruh tani untuk menambah total pendapatan keluarga. Sejalan dengan penelitian Wijaya et al., (2013) menyatakan bahwa jumlah tanggungan keluarga mempunyai pengaruh positif terhadap pendapatan rumah tangga. Penelitian Manalu et al. (2014) menunjukkan bahwa jumlah tanggungan keluarga mempengaruhi wanita untuk bekerja sebagai buruh harian lepas. Kristina et al. (2019) mengungkapkan bahwa banyaknya tanggungan di dalam keluarga mempengaruhi keputusan wanita tani dalam bekerja.

Tabel 3. Hasil Uji Analisis

\begin{tabular}{lccc}
\hline \multicolumn{1}{c}{ Variabel } & $\mathrm{B}$ & thitung. & Sig. \\
\hline Pendapatan Rumah Tangga & -1.089 & 3.007 & 0.005 \\
Tanggungan Keluarga & .167 & 3.247 & 0.003 \\
Pendidikan & .002 & .256 & 0.799 \\
Waktu Luang & -.074 & -.783 & 0.440 \\
Jarak rumah ke ladang & -.261 & -2.494 & 0.018 \\
Gotong royong & -.066 & -.773 & 0.445 \\
\hline
\end{tabular}

R Square $=0.554$

\section{Sumber: Data Primer Diolah, 2019.}

\section{3) Pendidikan}

Pendidikan $\left(\mathrm{X}_{3}\right)$ nilai signifikansinya sebesar 0,799 , sehingga dapat disimpulkan bahwa pendidikan wanita tidak berpengaruh nyata secara statistik teradap pengambilan keputusan untuk bekerja dengan tingkat kesalahan 10\%. Wanita yang menjadi tenaga kerja tani bukan karena status pendidikannya rendah, meskipun rata-rata responden yang menjadi tenaga kerja wanita tani berpendidikan SD. Sebagian tenaga kerja ada juga yang lulusan SMP dan SMA sederajat yaitu sebesar 21,62\% dari total responden. Artinya status pendidikan bukan menjadi faktor pengambilan keputusan wanita untuk menjadi tenaga kerja tani karena meskipun lulusan SMP dan SMA masih mau bekerja sebagai buruh tani.

Sebagian responden yang status pendidikannya hanya lulusan SD tetapi tidak bekerja karena penghasilan dari keluarganya sudah mencukupi untuk memenuhi kebutuhan sehari-hari. Apriliana et al. (2016) mengatakan bahwa variabel umur tidak berpengaruh terhadap pengambilan keputusan. Berbeda dengan penelitian yang dilakukan oleh Wulandari et al., (2017) menunjukkan bahwa variabel usia tidak berpengaruh nyata terhadap pengambilan keputusan wanita untuk bekerja.

\section{4) Waktu Luang}

Waktu Luang $\left(\mathrm{X}_{4}\right)$ nilai signifikansinya sebesar 0,440, sehingga dapat disimpulkan bahwa adanya waktu luang yang dimiliki oleh wanita tidak berpengaruh nyata secara statistik terhadap keputusannya untuk menjadi tenaga kerja tani dengan tingkat kesalahan 10\%. Banyak wanita di pedesaan yang hanya sebagai ibu rumah tangga dalam arti tidak memiliki pekerjaan yang menghasilkan uang. Meskipun memilki waktu luang tetapi dia memutuskan untuk 
tidak bekerja khususnya dibidang pertanian karena tidak memiliki lahan atau lahannya jauh serta hasilnya hanya sedikit. Berbeda dengan penelitian Manalu et al. (2014) yang mengungkapkan bahwa salah faktor yang mempengaruhi wanita bekerja yaitu mengisi waktu luang dengan bekerja atau menjadi tenaga kerja.

\section{5) Jarak Rumah ke Ladang.}

Jarak rumah ke ladang $\left(\mathrm{X}_{5}\right)$ nilai signifikansinya sebesar 0,018, sehingga dapat disimpulkan bahwa faktor tersebut berpengaruh nyata secara statistik dengan tingkat kesalahan $10 \%$ dalam pengambilan keputusan wanita untuk bekerja. Jika sawahnya jauh, maka wanita tidak mau untuk menjadi tenaga kerja diproses budidaya manapun dengan alasan ada pekerjaan dirumah. Apabila sawahnya dekat, maka wanita bersedia menjadi tenaga kerja karena tidak memakan waktu lama dalam perjalanan serta menguras tenaga kecuali si pemilik tanah bersedia menjemput semua tenaga kerja menggunakan tranportasi seperti pickup mini.

\section{6) Sistem Gotong Royong}

Sistem gotong royong $\left(\mathrm{X}_{6}\right)$ secara statistik tidak berpengaruh nyata terhadap keputusan wanita untuk bekerja dengan tingkat kesalahan $10 \%$. Artinya meskipun tidak bayar dengan uang tetapi hanya dengan sebungkus nasi atau dibayar pun tidak mempengaruhi wanita untuk tetap bekerjasebagai wanita tani. Sebagian adat pedesaan dalam melakukan proses budidaya ada yang menggunakan sistem arisan (gotong royong), artinya jika sekarang si A membantu si B dan dikemudian hari si B ingin melakukan proses budidaya maka si A akan ikut menolong. Akan tetapi sistem tersebut tidak mempengaruhi wanita untuk menjadi tenaga kerja tani.

Dari 6 variabel independen yang dianalisis, terdapat 3 yang berpengaruh nyata dan signifikan yang berpengaruh terhadap pengambilan keputusan wanita untuk menjadi buruh tani yaitu pendapatan rumah tangga, tanggungan keluarga dan jarak rumah keladang. Nilai $R$ square sebesar 0,554 menunjukkan bahwa variabel-variabel yang dimasukkan dalam model yang yang meliputi pendapatan rumah tangga, tanggungan keluarga, pendidikan, waktu luang, jarak dari rumah ke ladang dan gotong royong menjelaskan sebesar 55,4\% terhadap pengambilan keputusan wanita untuk bekerja sebagai tenaga kerja tani. Sisanya sebesar $44,6 \%$ dijelaskan atau dipengaruhi oleh faktor lain yang tidak dimasukkan dalam model seperti pendidikan setiap masing-masing tanggungan, pinjaman dan lainnya.

\section{Curahan Waktu Kerja Wanita Tani}

Kegiatan usahatani yang dilakukan wanita tani dipengaruhi oleh curahan waktu kerja. Artinya semakin luas lahan yang digunakan maka curahan waktu yang digunakan semakin besar. Curahan waktu kerja tergantung pada status pekerjaan yang dilakukan kontribusi wanita tani yang berupa alokasi waktu dalam usaha tani adalah merupakan keterlibatan wanita tani dalam hal ini istri petani untuk meningkatkan produksi yang baik. Pada kondisi ini, kontribusi diberikan wanita tani meliputi kontribusi tenaga kerja yang merupakan sebesarnya alokasi waktu kerja yang diberikan oleh wanita tani dalam usaha tani.

Dalam penelitian ini alokasi yang dihitung adalah alokasi wanita dalam berusahatani bawang daun mulai dari persiapan lahan sampai dengan pasca panen karena rata-rata usahatani yang dijalankan di daerah penelitian adalah usahatani bawang daun. Berdasarkan hasil penelitian waktu kerja wanita tani dalam kegiatan usaha tani bawang daun dapat dilihat pada Tabel 4.

Tabel 4. Curahan Waktu Kerja Wanita Tani Dalam Kegiatan Usaha Tani Bawang Daun di Desa Pegantenan

\begin{tabular}{cccc}
\hline No & Jenis kegiatan & Jam & Rata2 HKP \\
\hline 1 & Teknik penanaman & 4 & 3,2 \\
2 & Pemeliharaan & 10 & 8,0 \\
3 & Panen & 4 & 3,2 \\
4 & Pasca panen & 2 & 1,6 \\
5 & Pemasaran & 1 & 0,8 \\
\hline
\end{tabular}

Sumber: Data Primer Diolah, 2019.

Berdasarkan Tabel 4. diatas menunjukan bahwa Waktu Kerja Wanita Tani dalam usaha tani bawang daun di Desa Pegantenan Kecamatan Pegantenan Kabupaten Pamekasan yaitu teknik penanaman sebesar 3,2 HKP, pemeliharaan sebesar 8,0 HKP, panen sebesar 3,2 HKP, pasca panen sebesar 1,6 HKP, pemasaran sebesar 0,8 HKP. Paling banyak waktu yang diguanakn yaitu pada pemeliharaan yang meliputi penyiraman, penanganan hama penyakit serta pemupukan. Jika di lihat dari curahan waktu baik HKP/ jam maupun HKP/ hari maka curahan waktu kerja wanita tani bawang daun khususnya pada panen merupakan keterlibatan wanita tani di Desa Pegantenan. 


\section{Kontribusi Pendapatan Kerja Wanita Tani}

Pendapatan tenaga kerja wanita tani rata-rata perbulan sebesar Rp. 418.606,-. Sedangkan pendapatan keseluruhan rumah tangga rata-rata Rp. 1.495.850,-. Hal ini menunjukkan bahwa kontribusi pendapatan tenaga kerja wanita sebesar 27,98\%. Meskipun persentase pendapatan wanita lebih kecil daripada pendapatan kepala rumah tangga, akan tetapi wanita juga mempunyai value yang tidak dibayar disamping menjadi ibu rumah tangga seperti mencuci, memasak, membersihkan rumah serta mengurus anak dan keluarga. Artinya, dengan kontribusi 27,98\% terhadap pendapatan rumah tangga tiap bulannya memberikan tambahan pendapatan yang dapat menunjang dalam memenuhi kebutuhan sehari-hari.

KTKW

$$
\begin{aligned}
& =\frac{\text { Rp. } 418.605}{\text { Rp. } 1.077 .245+\text { Rp. } 418.605} \times 100 \% \\
& =\frac{\text { Rp. } 418.605}{\text { Rp. } 1.495 .850} \times 100 \% \\
& =27,98 \%
\end{aligned}
$$

Meskipun dari hasil perhitungan kontribusi pendapatan buruh tani sebesar 27,98\% atau tergolong kecil akan tetapi melihat jumlah total pendapatan sebesar Rp. 1.495.850,-/bulan, maka diharapkan wanita tetap bekerja untuk membantu menambah pendapatan rumah tangga.

Penelitian yang dilakukan oleh Sopamena et al., (2018) yang menunjukkan bahwa pendapatan tenaga kerja dari wanita berkontribusi sebesar 20-30\% terhadap pendapatan rumah tangga. Hasil Penelitian Fauzan et al., (2020) juga menunjukkan bahwa hasil pendapatan wanita yang bekerja sebagai buruh petik melati gambir yang mampu memberikan kontribusi sebesar 25,58\% terhadap total pendapatan rumah tangga.

\section{KESIMPULAN}

Faktor-faktor yang berpengaruh nyata terhadap pengambilan keputusan wanita untuk bekerja sebagai wanita tani yaitu karena pendapatan rumah tangga yang rendah, jumlah tanggungan keluarga serta jarak dari rumah ke sawah dengan tingkat kesalahan 10\%. Sedangkan yang paling berpengaruh yaitu jumlah tanggungan keluarga dengan persentase kesalahannya hanya $0,3 \%$. Semakin banyak jumlah anggota keluarga maka pengeluaran tiap bulannya semakin banyak yang membuat keputusan wanita untuk menjadi tenaga kerja tani untuk memenuhi kebutuhan sehari-hari. Meskipun berperan sebagai ibu rumah tannga akan tetapi wanita juga memberikan kontribusi pendapatan hasil bekerja sebagai wanita tani sebesar $27,98 \%$ terhadap pendapatan total keluarga. Diharapkan wanita tetap melakukan kegiatan usahatani disamping sebagai ibu rumah tangga untuk memenuhi kebutuhan sehari-hari karena pendapatan rata-rata total rumah tangga rata-rata $\mathrm{Rp} .1 .495 .850,-. /$ bulan.

\section{DAFTAR PUSTAKA}

Anggraini, E., Priyono, B. S. dan Sriyoto. 2020. Faktor Penentu Pendapatan Wanita Buruh Tani Padi Sawah dan Kontribusinya Terhadap Pendapatan Keluarga (Studi Kasus : di Desa Wonosari Kecamatan Megang Sakti Kabupaten Musi Rawas). Agrisep, 19(1): 109-126.

Arsal T, Basri M, Tono S. 2017. Contribution of Rural Women to Family Economy through Informal Sector Activities. International Journal

Indonesian Society and Culture,9 (1): 136-142.

Azizah. 2017. Pengaruh pendapatan pekerja perempuan terhadap pendapatan keluarga. Program Study Ekonomi Syariah. Fakultas Ekonomi dan Bisnis Islam. Institut Agama Islam Negeri. Purwokerto.

Badan Pusat Statistik. 2018. Pendataan Sosial Ekonomi. Badan Pusat Statistik. Jakarta.

Bano, S., Faridi, M. Z., \& Bashir, F. 2012. Rural Women's Contribution in Family Budget: A CaseStudy of District Layyah. Journal Sustainable Development, 3(10): 1-9.

Endang, R. P., Tenaya, I. Narka, dan Astiti, N.W. 2014. Peran Wanita Tani dalam Penerapan Teknologi Pengelolaan Tanaman Terpadu (PTT) pada Usaha Tani Jagung di Kecamatan Pringga Baya Kabupaten Lombok Timur. Jurnal Manajemen Agribisnis, Vol.2 (1) : 76-83.

Enete A, Amusa T A. 2010. Contribution of Men and Women to Farming Decisions in Cocoa Based Agroforestry Housholds of Ekiti State, Nigeria. Tropicultura, 28 (2): 77-83.

Ervinawati, V., Fatmawati dan Lendang, I. 2015. Peranan Kelompok Wanita Tani Perdesaan dalam Menunjang pendapatan Keluarga. Thesis, Program Studi 
Mohammad Shoimus Sholeh, Lia Kristiana, dan Maulidatul Hasanah. Kontribusi Tenaga Kerja Wanita Dalam Berusahatani di Desa Pegantenan Kecamatan Pegantenan Kabupaten Pamekasan

Sosiologi Magister Ilmu Sosial Fakultas Ilmu Sodial dan Ilmu Politik Universitas Tanjung pura. Pontianak.

Muhammad Fauzan, M., Martinah, U. dan Rahayu, L. 2020. Curahan Waktu Kerja Wanita Tani Sebagai Buruh Petik Melati Gambir dan Kontribusinya

Terhadap Pendapatan Rumah Tangga. Jurnal Pemikiran Masyarakat Ilmiah Berwawasan Agribisnis, 6(2): 803-811.

Ilma B, Muis Abdul. 2015. Contribution of Female Oil Palm Growers on Household Income at the KasoloangVillage, North Mamuju. J. Agrotekbis, 3(2) : 231 - 239.

Kristina, A. Immamudin. 2019. Konflik Gender di Pasar Tenaga Kerja Wanita Tani (Studi Fenomenologi Wanita Tani dalam Membuat Keputusan Kerja). Jurnal SIMULARCA, 2(1): 91-100.

Manalu, A. Rosyani. Nainggolan, S. 2014. Faktor-Faktor Yang Mempengaruhi Wanita Bekerja Sebagai Buruh Harian Lepas (BHL) di PT. Inti Indosawit Subur Muara Bulian Kecamatan Maro Sebo Ilir Kabupatenbatanghari. Jurnal Sosio Ekonomika Bisnis 17(2): 81-93.

Mardani, T. M. Nur, Satriawan H. 2017. Analisis Usaha Tani Tanaman Pangan Jagung di Kecamatan Juli Kabupaten Bireuen. Jurnal S. Pertanian, 1(3): 203-204.

Nilakusmawati, D. P. E. Susilawati, Made. 2012. Studi Faktor-Faktor yang Mempengaruhi Wanita Bekerja di Kota Denpasar. Jurnal PIRAMIDA, VIII(1): 26-31.

Prasetya, N. R. dan Putro, S. 2019. Hubungan Tingkat Pendidikan dan Umur Petani dengan Penurunan Jumlah Rumah Tangga Usaha Pertanian Sub Sektor Tanaman Pangan di Desa Meteseh Kecamatan Boja Kabupaten Kendal. Edu geography, 7(1): 47-56.

Pratiwi, C. A., gunawan, D. S. dan istiqomah. 2018. Analisis Ekonomi Usahatani Padi Dan Kelayakan Rumah Tangga Tani di Desa Sambeng Kulon Kecamatan Kembaran Kabupaten Banyumas. JSEP,11(1): 33-45.

Ridwan, A., lestari, R.D. dan Fanani, A. 2019. Curahan Tenaga Kerja dan Kontribusi Pendapatan Wanita Tani dalam Rumah Tangga Petani Miskin Penerima Program Keluarga Harapan (PKH) di Kecamatan Kedungadem Kabupaten Bojonegoro. Jurnal Ekonomi Pertanian dan Agribisnis, 3(1): 33-42.

Risky Wulandari, R., Rochaida, E. dan Lestari, D. 2017. Faktor Yang Mempengaruhi Keputusan Istri Bekerja Berdomisli Di Kelurahan Sidodadi Kecamatan Samarinda Ulu. Jurnal Ilmu Ekonomi Mulawarman, 2(3).

Rivai, A., Sinaga, B. M., Siregar, H. dan Harianto. 2020. Karakteristik Rumahtangga Petani Usaha Padi Penerima PKH di Kabupaten Karawang, Jawa Barat. Jurnal Ekonomi Pertanian dan Agribisnis, 4(1): 123-132.

Sopamena, J. F., dan August, E. P. 2018. Tnyafar: Women, Livelihoods Strategy in Selaru Island, West Southeast Maluku District. International Journal of Environment, Agriculture and Biotechnology (IJEAB), 3(5): 16851690.

Subri, M. 2003. Ekonomi Sumberdaya Manusia. PT. Raja Grafindo Persada. Jakarta.

Talipi S B, Olfie B L S, Moniaga V R B. 2018. Kontribusi Ibu Rumah Tangga Terhadap Pendapatan Keluarga. AgriSosioEkonomi,14(1): $417-424$.

Ware J O. 2014. Women's Productive and Economic Roles towards Household Poverty Reduction in Ghana. A Survey of Bongo District in Northern Ghana. Research on Humanities and Social Sciences, 4(19): 148-155.

Wijaya, I.M.A., Wirathi, I.G.A.P. 2013. Faktor-Faktor Yang Mempengaruhi Pendapatan Ibu Rumah Tangga Yang Bekerja Pada Sektor Informal di Kelurahan Dauh Puri Kauh, Denpasar Barat. E-Jurnal

EP

Unud,

2(5):

269-276. 